\title{
BALTIJOS ŠALIŲ FINANSINIO STABILUMO IR RIZIKOS VERTINIMAS
}

\author{
Veronika DZALBO*, Laura GUDELYTE் \\ Vilniaus Gedimino technikos universitetas, Verslo vadybos fakultetas, \\ Finansų inžinerijos katedra, Sauletekio al. 11, LT-10223, Vilnius, Lietuva \\ *El.paštas veronika.dzalbo@stud.vgtu.lt
}

\begin{abstract}
Santrauka. Tikslingas šalies rizikos vertinimas yra svarbus ir su kiekvienais metais tampa vis aktualesne tema. Investuotojai, siekdami suprasti, ar gali saugiai investuoti, taiko ne vieną metodą, siekdami nustatyti, ar šalis yra tinkama investavimui. Šiame straipsnyje siekiama įvertinti Baltijos šalių riziką ir identifikuoti rizikingiausią šalị. Taigi pradžioje apibūdinami šalies rizikos vertinimo metodai, paaiškinama, kas yra finansinis patikimumas, apžvelgiami kredito reitingai, palūkanų normos, CDS tarp valstybių. Tuomet taikant koreliaciją, regresiją, SAW metodus bei atliekant lyginamąją rodiklių analizę identifikuojama Baltijos rizikingiausia šalis.
\end{abstract}

Reikšminiai žodžiai: ekonominė rizika, finansinis stabilumas, reitingai, stabilumo indeksai, šalies rizika, šalies rizikos vertinimo metodai.

\section{Ivadas}

Kiekvienos šalies finansu sektorius, kurios reikšmingą dali sudaro bankų sektorius, draudimo sektorius, kitu investiciniu paslaugu sektorius yra svarbi šalies ekonomikos dalis. Normaliomis sąlygomis finansų sektoriuje siekiama santaupas efektyviai investuoti ị produktyvius pramonès ir paslaugų bei namų ūkių sektorius, kurie gali padidinti savo produkcijos ir paslaugų apimtị. Taip finansų sektorius, nemaža dalimi skolos forma finansų rinkose perskirstydamas kapitalo srautus ir derindamas investuotojų bei skolininkų interesus, taip pat prisiimdamas ir perskirstydamas riziką dèl neapibrěžtumo ateityje, daro reikšmingą ịtaką kiekvienos šalies bendrojo vidaus produkto (toliau BVP) augimui. Dèl šios priežasties svarbu, kad makroekonominé, politinè ir socialinè aplinka valstybèje būtų kuo stabilesnè. Tačiau ir ji ne visuomet yra stabili, ir tai lemia investuotojų lūkesčius bei polinki rizikuoti ir toleruoti neapibrèžtumą ateityje.

Analizuojant bet kurią šalị kaip potencialių investicijų vietą, reikia tinkamai ịvertinti jos rizikingumą, ir tai yra aktuali tema dèl investavimo galimybių pasaulyje gausos. Paskolų ar kitų fiksuoto pajamingumo finansinių instrumentų palūkanų normų lygis labiausiai priklauso nuo situacijos tarpbankinèje rinkoje, skolinimo sąnaudų, skolininko rizikingumo ir makroekonominès padèties valstybèje, t. y. bendro rizikingumo, susijusio su investavimu. Investuotojams svarbu valdyti ir teisingai ịvertinti kiekvienos šalies riziką, kad nepasikartotų situacija kaip 2008$2011 \mathrm{~m}$. vykusi finansinè krizė, kuri gerokai paveikè šalių realiają ekonomiką bei padarè neigiamą ịtaką gyventojų socialinei gerovei (Pati, 2017). Šalies rizika priklauso nuo daugelio ịvairių veiksnių, tačiau pagrindiniai bendrosios šalies rizikos šaltiniai yra susiję su politiniais ir ekonominiais procesais bei apskritai su socialine šalies raida: politiné rizika, politinè-karinè ir ekonominè rizika, kurios gali turèti ịtakos šalies verslui ir lemti investuotojų nuostolius. Taip pat vertètų atkreipti dèmesị ir ị faktą, kad klimato kaita irgi gali būti svarbus šalies riziką lemiantis veiksnys (pvz., 2020 m. pradžioje vykusių didelio masto gaisrų Australijos miškuose atvejis).

Finansinè integracija, globalizacija ir informacinių technologijų inovacijos reikšmingai padidino valstybiu finansų sistemų tarpusavio priklausomybę, todèl ilgainiui tapo svarbu, kad skirtingų šalių finansinio stabilumo rodikliai galètų būti korektiškai palyginami, jų nustatymo metodikos turètų būti bendrai patvirtintos tarptautiniu mastu (Freitakas ir Mendelsonas, 2016). Dèl globalizacijos kapitalo judejimas tarp valstybiu tapo paprastesnis, tačiau tai lemia ir didesnę investicijų valdytojų atsakomybę bei didina poreikị tiksliai ịvertinti šalių ekonominę padètí, tad reikia vertinti šalių rizikingumą dèl ekonominių nuosmukių užkrečiamumo grèsmès, investicinio ir skolinimo kapitalo saugumo užtikrinimo. Investuotojai, siekdami suprasti, ar gali saugiai investuoti, taiko ne vieną metodą, bandydami nustatyti, kiek šalis yra tinkama kapitalo investavimui, tad naudojasi įvairia analitine informacija. Yra daug ịvairių būdų analizuoti šalies riziką, nustatant turto riziką (šalies skolos) arba patikrinus nepriklausomus reitingus vienoje iš kredito reitingo agentūrų, iš kurių labiausiai žinomos Standard \& Poor's, Moody's Investors Service ir Fitch Ratings, tačiau šalies rizikos nustatymo tyrimuose didelę ịtaką daro matavimo metodai, kuriuos taikant galima įvertinti ekonominę riziką, t. y. finansinį valstybès patikimumą. Be to, nuolatinè tokio pobūdžio rodiklių stebẻsena ir atitinkamų sprendimų prièmimas gali padèti išvengti valstybès rizikos didèjimo pasekmių, o prasidejjus finansinei krizei sumažinti jos žalą šalies ekonomikai ir sutrumpinti atsigavimo laikotarpi. 
Tyrimo problema - šalies rizikos ir jos priklausomybės nuo makroekonominių veiksnių kiekybinio vertinimo metodų trūkumas.

Tyrimo objektas - šalies rizika ir jos vertinimas.

Tyrimo tikslas - palyginti Baltijos šalių rizikas ir identifikuoti rizikingiausią šalį.

Tyrimo uždaviniai:

1. Apibūdinti šalies rizikos vertinimo teorinius aspektus.

2. Išnagrinèti Baltijos šalių rizikos rodiklius.

3. Nustatyti rizikingiausią Baltijos šalị.

Tyrimo metodai - mokslinių straipsnių sisteminè analizė, internetinių puslapių duomenų analizė bei apibendrinimas, gautų duomenų analizè.

\section{1. Šalies rizikos vertinimo teoriniai aspektai}

Šalies riziką lemia daug ịvairių veiksnių, tačiau pagrindinès rizikos yra politinė rizika, politinè-karinè ir ekonominė rizika, kurios gali turèti ịtakos šalies verslui ir lemti investuotojų nuostolius. Ekonominè rizika susijusi su esama šalies finansine būkle ir gebèjimu grąžinti skolas kitoms valstybėms ar investuotojams, politinė rizika susijusi su šalies politinėmis strategijomis bei sprendimų poveikiais investicijoms. O politinè-karinè rizika susijusi su karine grèsme iš užsienio (žr. 1 lentelę). Kai kuriais atvejais ekonominè, politinè bei politinè-karinè rizika gali būti glaudžiai susijusios ir būdingos ne tik atskirai šaliai, bet ir platesniam regionui. Šios rizikos rūšys bei jas apibūdinantys veiksniai yra svarbūs investuotojams, kurie ịprastai stebi ir analizuoja tiek ekonominę, tiek politinę situaciją šalyse, siekdami tikslingai ir tinkamai investuoti. Siekdami saugiai ir pelningai investuoti kapitalą, investuotojai turi atsižvelgti ị daug skirtingų veiksnių, kurie gali daryti įtaką palūkanų normoms, kurių aukštas lygis gali kenkti šalies verslui ir vertybinių popierių rinkai, ịtakingų politikų ir kitų visuomenės veikejjų viešai pateikiamą informaciją, pvz., apie būsimus planus, kurie turi reikšmingos ịtakos besiformuojantiems atitinkamiems rinkos lūkesčiams, kurie taip pat gali daryti reikšmingą įtaką šalies rizikos raidai.

Be politinių, reputacinių ir ilgalaikių ekonominès raidos sutrikimų ir kitų pasekmių šalies rizika reiškia tikimybę, kad skolininkas, t. y. valstybè, kuri yra įsiskolinusi kitai šaliai, nevykdys savo finansinių įsipareigojimų (kredito rizika). Tokia rizika kyla dèl šalies fiskalinès politikos, kuomet valstybė neteisingai formuoja biudžetą, neteisingai koreguoja mokesčius arba reguliuoja valstybès skolą (Husted ir de Sousa-Filho, 2017). Didelès rizikos ir stipraus neapibrèžtumo sąlygomis didinant valstybės skolą ne tik kenkiama, bet ir padedama kriziniu laikotarpiu šalies ekonomikos augimui, nes valstybès skola gali būti nukreipiama ị vidaus vartojimą, t. y. vidaus paklausos didinimą. Kita vertus, neigiamas valstybès skolos poveikis ekonomikos augimui tampa silpnas esant žemai politinei ir finansinei rizikai, o padidejusi valstybès skola galètų padèti skatinti ekonomikos augimą esant nedidelei rizikai (Karazijienè ir Sabonienė, 2009). Be to, dèl šalių pajamų ir skolos lygių skirtumų šalies rizika daro skirtingą ịtaką skolos augimui. Tai rodo, kad šalies vyriausybė turètų tinkamai skolintis, atsižvelgdama ị dabartinę rizikos aplinką, tuo pačiu siekdama gerinti ekonominius rezultatus.

Šalies rizikos vertinimas - procesas, kuriame pripažįstamas tam tikras rizikos pasekmių egzistavimas ir galimybė tai ịvertinti, atsižvelgiant $\mathfrak{i}$ visus rizikos veiksnius, jų poveikio galimybes ir mastą, recipientų ir aplinkos būseną (Damodaran, 2018). Šio proceso esmè yra tai, kad siekiama įvertinti negatyvaus įvykio pasekmes, atsižvelgiant ị pagrindinius visiems recipientams daromus poveikius, kuriuos jie patiria iš ịvairių grèsmės šaltinių. Atskiru atveju, valstybės valdomos įmonès gali patirti finansinę - rinkos, kredito (sandorio šalies) ir likvidumo (investuojant) - riziką, kuri pasireiškia valdant piniginius išteklius ir atliekant kitas jų veiklai užtikrinti būtinas finansines operacijas. Šiuo atveju svarbu, kad valstybès valdomose ịmonèse būtų skiriamas tinkamas dèmesys efektyviai finansinès rizikos valdymo politikai suformuoti ir jai igyvendinti. Be to, reikšmingą įtaką kredito rizikos lygiui turi esamo ar potencialaus skolininko ịsiskolinimo lygis, lemiantis skolininko ekonominès situacijos raidą ateityje. Iprastoje kreditavimo veikloje dažniausiai jis tiesiogiai siejamas su kredito rizikos lygiu, tačiau valstybių atveju toks sąryšis galioja palyginti retai.

Tiek užsienio, tiek vietos investuotojams svarbiausios kliūtys investicijoms yra politinio nestabilumo baimė. Kitaip tariant, stabilios politinès sistemos nebuvimas, karinè grèsmė ir dažni vyriausybės politikos pokyčiai lemia reikšmingą neapibrèžtumą dèl ateities. Todèl politinis nestabilumas, susijęs su didesne šalies rizika, taip pat lemia ekonomikos nuosmukį ir neišvengiamą finansinę riziką (Liu et al., 2020) (žr. 1 lentelę).

Padidejjęs politinis-karinis, finansinis ir ekonominis neužtikrintumas lemia didesnị šalies valiutos kurso svyravimą, kuris tuo pačiu sumažina investuotojų pasitikejjimą ir pagreitina kapitalo nutekejjimą, dèl kurio reikšmingai sumažèja šalies tarptautinès atsargos (Liu et al., 2020). Oficialus valiutos kursas gali nukrypti nuo pusiausvyros kurso dèl išorinių ir vidinių veiksnių (šaliai nepalankių geopolitinių procesų, investuotojų pesimistiškų lūkesčių ar netgi panikos ir t. t.). Šie sukrėtimai padidina šalies rizikos lygị ir yra ypač dideli, kai šalis turi silpnus makroekonominius pagrindus, nepakankamai išvystytą finansinę sistemą ar skurdžią politinę sistemą. Taigi didesni sukrètimai lemia didesnị valiutų kurso svyravimą. 
1 lentelè. Šalies rizikos komponentai (sudaryta, remiantis Liu et al., 2016)

\begin{tabular}{|c|c|c|}
\hline Rizika & Kas sudaro? & Makroekonominiai veiksniai \\
\hline $\begin{array}{l}\text { Politinè-karinè } \\
\text { rizika }\end{array}$ & $\begin{array}{l}\text { Valstybių narių dalyvavimas, gynyba, karinès pajègos, } \\
\text { suderinamumas su įsipareigojimais NATO }\end{array}$ & $\begin{array}{l}\text { ES išlaidos gynybai, karinių pajègų } \\
\text { mastas }\end{array}$ \\
\hline Politinè rizika & $\begin{array}{l}\text { Vyriausybės stabilumas } \\
\text { Socialinės ir ekonominės sąlygos } \\
\text { Investicijų profilis } \\
\text { İstatymai ir tvarka }\end{array}$ & $\begin{array}{l}\text { Valstybės biudžeto pajamos ir jų } \\
\text { naudojimas, nedarbo lygis, akcijų rinka, } \\
\text { akcijų rinkos grąžos norma, bendroji } \\
\text { investicijų apimtis, atsakas į politiką }\end{array}$ \\
\hline Ekonominè rizika & $\begin{array}{l}\text { BVP vienam gyventojui, realusis metinis BVP augimas, } \\
\text { metinė infliacija, biudžeto apimties santykinė dalis nuo } \\
\text { BVP, einamosios sąskaitos santykinè dalis nuo BVP }\end{array}$ & $\begin{array}{l}\text { Infliacijos lygis, biudžeto apimtis, } \\
\text { einamosios sąskaitos likutis }\end{array}$ \\
\hline Finansinè rizika & $\begin{array}{l}\text { Skolų aptarnavimo išlaidų santykinė dalis nuo prekių ir } \\
\text { paslaugų eksporto, einamosios sąskaitos santykinè dalis } \\
\text { nuo prekių ir paslaugų eksporto, valiutos kurso } \\
\text { stabilumas (santykinis pokytis) }\end{array}$ & $\begin{array}{l}\text { Grynasis eksporto apimtis, einamosios } \\
\text { sąskaitos likutis, valiutos kurso lygis }\end{array}$ \\
\hline
\end{tabular}

\section{1. Šalies finansinio patikimumo sampratos analizė}

Siekiant įvertinti finansinio patikimumo svarbą, reikia išnagrinèti visą pinigų politikos stabilumo, finansinio stabilumo ir finansinès priežiūros struktūrą. Finansinių išteklių perskirstymo procese išskiriami trys pagrindiniai finansų rinkos dalyvių, kurių elgsena makroekonominiu lygiu sukelia finansų krizes, tipai:

- skolintojai, kurie turi lèšų perteklių (gyventojai, įmonès, Valstybẻ ar užsienio subjektai);

-tarpininkai, per kuriuos vyksta lěšų judèjimas (ịmonès, Valstybė ir savivaldybės, gyventojai bei visuomeninès organizacijos);

- skolininkai arba kapitalo vartotojai (bankai ir kitos kredito įstaigos, draudimo bendrovés, pensijų ir investiciniai fondai).

Pinigų politikai ir finansų sistemai gali būti nustatomi keturi skirtingi tikslai: pinigų politikos stabilumas, finansinis stabilumas (makroekonominis), finansiniu institucijų stabilumas (mikroekonominis), drausmingos ir gerai veikiančios rinkos bei tinkamas vartotojų elgesys (verslo etika) (Freitakas ir Mendelsonas, 2016) (žr. 2 lentelę).

2 lentelè. Pinigų politikos ir finansų sistemos struktūra (sudaryta, remiantis Freitakas ir Mendelsonas, 2016)

\begin{tabular}{|c|c|c|}
\hline Politika & Tikslas & Galutinis tikslas \\
\hline Monetarinė politika & Kainų stabilumas & \multirow{2}{*}{$\begin{array}{l}\text { Stabilus ekonominis } \\
\text { augimas }\end{array}$} \\
\hline Makrolygio rizikos ribojimas & Finansinis stabilumas & \\
\hline Mikrolygio rizikos ribojimas & Finansų institucijų tvarumas & \multirow[t]{2}{*}{ Vartotojų apsauga } \\
\hline Verslo etika & Drausmingos rinkos ir teisingas vartotoju elgesys & \\
\hline
\end{tabular}

Remiantis Haldane et al. (2004) pasiūlyta interpretacija, finansinis stabilumas ir finansinis patikimumas yra taupymo ir investavimo tarpusavio ryšio pagrindas. Taigi finansinis nestabilumas pagal šiuos mokslininkus gali būti apibrěžiamas kaip dèl finansų sektoriaus trūkumų atsirandantis bet koks reikšmingas nukrypimas nuo optimalaus taupymo bei investavimo ekonominio plano. Be to, šie tyrëjai finansini nestabilumą sieja su iš jo kylančiomis finansų krizèmis. Kita vertus, Schinasi (2004) šalies finansų sistemos stabilumą siejo su tokia jos būkle, kuomet rinkoje yra sukurtos ir užtikrintos visos būtinos prielaidos atlikti pagrindines savo funkcijas: laiko ir erdvès atžvilgiu perskirstyti išteklius, tinkamai ịvertinti gręsiančią riziką bei atlaikyti vidaus ir išorès neigiamų veiksniu ịtaką. Be to, šalies finansų sektoriaus stabilumas taip pat gali būti apibrěžiamas kaip visos finansų sistemos ilgalaikis atsparumas ịvairaus pobūdžio vidiniams ir išoriniams sukrètimams, taip kuo labiau mažinant finansinio tarpininkavimo proceso sutrikimo grèsmę, kad tai galètų pakenkti finansinių išteklių perskirstymo procesui, t. y., sklandžiam ir racionaliam investavimui (žr. 3 lentelę).

3 lentelè. Valstybès rizikingumo veiksniai (Freitakas ir Mendelsonas, 2016)

\begin{tabular}{|l|l|}
\hline \multicolumn{1}{|c|}{ Veiksnys } & \multicolumn{1}{c|}{ Daroma ịtaka } \\
\hline Ekonominė rizika & $\begin{array}{l}\text { Itakoja galimybes surinkti mokestines pajamas ateityje ir skolos aptarnavimo galimybes, lemia } \\
\text { investicinės aplinkos kokybę ir ekonominį patrauklumą užsienio investuotojams }\end{array}$ \\
\hline Skolos lygis & $\begin{array}{l}\text { Lemia valstybės mokumo perspektyvas ateityje bei ateities fiskalinę politiką. Tai daro ịtaką } \\
\text { šalies privataus sektoriaus ekonominei elgsenai bei tiesiogines užsienio investicijas }\end{array}$ \\
\hline
\end{tabular}


3 lentelès pabaiga

\begin{tabular}{|c|c|}
\hline Veiksnys & Daroma įtaka \\
\hline Fiskalinè politika & $\begin{array}{l}\text { Susijusi su skolos akumuliavimu dabartyje ir ateityje, tiesiogiai įtakoja valstybès riziką ir } \\
\text { netiesiogiai valstybės rizikingumą dèl fiskalinès politikos }\end{array}$ \\
\hline Tarptautinè prekyba & $\begin{array}{l}\text { Atitinka šalies mokumo galimybes ir perspektyvas ateityje. Tarptautinės prekybos perteklius, } \\
\text { atitikdamas stiprų ekonomikos konkurencingumą, stimuliuoja ekonomiką, didina šalies } \\
\text { stabilumą ir patrauklumą užsienio investicijoms }\end{array}$ \\
\hline Sisteminè rizika & $\begin{array}{l}\text { Finansų rinkų tarpusavio priklausomybė lemia nediversifikuojamą rizikos dalį. Valstybės } \\
\text { jautrumas globaliems svyravimams lemia jos investicinį patrauklumą }\end{array}$ \\
\hline Monetarinè politika & $\begin{array}{l}\text { Šalies priklausymas pinigų sajungai arba priklausomybe nuo užsienio valiutos lemia valstybės } \\
\text { rizikos kaitą priklausomai nuo atitinkamų valiutos kurso svyravimų }\end{array}$ \\
\hline Rizikingumo reitingas & Valstybès reitingas lemia rinkos vertinimą ir daro įtaką tiesioginių užsienio investicijų lygiui \\
\hline
\end{tabular}

Siekiant išlaikyti šalies finansinị stabilumą ir tinkamai jị prižiūrèti, daugiausia centrinių bankų pastangomis taikoma makroprudencine politika (viena iš finansų sistemos stabilumo apsaugos), kuri yra viena iš reguliaciniu priemonių, padedančių išvengti sisteminès rizikos bei palaikyti visos finansų sistemos stabilumą, kurị vykdo už tai atsakingos ES ir nacionalinès institucijos, Lietuvos atveju - Lietuvos bankas. Šalies finansinis nestabilumas atsiranda, kai pasirodę neigiami (dažnai - išoriniai rinkos) veiksniai pradeda daryti įtaką šalies ekonomikai. Šis reiškinys apibrěžiamas trimis pagrindiniais kriterijais (Dumalakas, 2018):

- didžiosios daugumos paskolų kaina (arba palūkanų normos) staiga reikšmingai nukrypsta nuo fundamentalios kainos (finansiniai burbulai);

- sutrikdomas finansų rinkų veikimas ir kreditavimo prieinamumas (tiek vidaus, tiek išorès);

- gerokai pasikeičia bendrosios išlaidos ir laikosi lygyje, kuris yra aukštesnis nei bendri ekonomikos gamybiniai pajègumai.

\section{2. Šalies rizikos vertinimo pagrindinių veiksnių analizė}

Šalies rizikai nustatyti yra taikomi tam tikri vertinimo būdai, kurie gali parodyti, ar rizika šiuo metu yra didelè ar maža, taip pat galima nustatyti preliminariai, kas laukia valstybės ateityje remiantis prieinamais duomenimis. Atlikus vertinimą, galima ir siūlyti tam tikrus būdus, būklei gerinti. Vertinant šalies riziką atsižvelgiama ị šiuos veiksnius, apibūdinant kintamuosius ir jų poveikị ekonominiam šalies rizikingumui (žr. 4 lentelę).

Šių veiksnių įtaka dažniausiai yra tiesiogiai susijusi su šalies rizika ir lemia valstybės investicinị patrauklumą, kas atitinka įtaką valstybės rizikingumui. Be to, formuojant investicinius portfelius ar priimant sprendimus dèl

4 lentelè. Šalies finansinio stabilumo vertinimo indeksai (sudaryta, remiantis Freitakas ir Mendelsonas, 2016)

\begin{tabular}{|c|c|}
\hline Stabilumo indeksai & Ką indeksai parodo? \\
\hline BVP pokytis & $\begin{array}{l}\text { Apibrezžia šalies ekonomikos augimą, apibūdina gyvenimo lygị, taip pat yra taikomas } \\
\text { ūkio raidai vertinti, įvairių šalių ekonomikos raidos lyginamajai analizei atlikti }\end{array}$ \\
\hline Palūkanų normos & Kredito kainos rodiklis arba investicijų grąžos norma \\
\hline Rinkos kapitalizacija & $\begin{array}{l}\text { Bendra vertė lygi nuosavo kapitalo vertei biržoje ir parodo, kaip tas įmones (rinką) } \\
\text { vertina investuotojai }\end{array}$ \\
\hline Infliacijos lygis & Kai kyla ne pavienių prekių ar paslaugų kainos, o bendras prekių ir paslaugų kainų lygis \\
\hline Biudžeto deficitas, \% & $\begin{array}{l}\text { Parodo, kiek reikia finansuoti valstybės biudžeto išlaidas ir kokiu mastu didèja valstybės } \\
\text { skola }\end{array}$ \\
\hline $\begin{array}{l}\text { Einamosios sąskaitos } \\
\text { deficitas, } \%\end{array}$ & $\begin{array}{l}\text { Atitinka prekių, paslaugų, pajamų ir einamųjų pervedimų judejjimą tarp šalies ir likusio } \\
\text { pasaulio, kai tuo tarpu kapitalo ir finansinè sąskaita pateikia informaciją apie finansinių } \\
\text { aktyvų ir įsipareigojimų srautų judėjimą tarp šalių }\end{array}$ \\
\hline Paskolos/indèliai & Parodo, kiek valstybèje gyvenantys asmenys yra linkę taupyti ir skolintis \\
\hline $\begin{array}{l}\text { Negrąžintinos finansinės } \\
\text { paramos }\end{array}$ & Programa, remianti/investuojanti ị tam tikrus projektus \\
\hline ROA ir ROE & Parodo investuotų pinigų grąžos normą \\
\hline Išmokètos paskolos, Eur. & Pinigų suma, kuri vèliau turi būti grąžinta \\
\hline $\begin{array}{l}\text { Pasaulio ekonomikos klimato } \\
\text { indeksas }\end{array}$ & \multirow{3}{*}{$\begin{array}{l}\text { Svarbūs indeksai vertinant kiekvienos atskiros šalies finansini stabilumą, nes visos } \\
\text { finansinės sistemos yra tarpusavyje susijusios ir kiekvieno pablogèjimas turi neigiamą } \\
\text { poveikị }\end{array}$} \\
\hline $\begin{array}{l}\text { Pasaulio ekonomikos augimo } \\
\text { tempas }\end{array}$ & \\
\hline Pasaulio infliacija & \\
\hline
\end{tabular}


investavimo, reikia atsižvelgti ị individualias kiekvienos investicijos ar sandorio ypatybes, taip pat būtina atsižvelgti i bendrą makroekonominę perspektyvą, nes skirtingi rizikos šaltiniai ir tipai sąveikauja tarpusavyje ir gali turèti itakos keliems, jei ne visiems ekonomikos sektoriams (Liu et al., 2016).

Taigi finansinio stabilumo matavimo metodų analizè gali padèti apibūdinti šalies riziką investuotojo požiūriu. Tai leidžia išsamiau ir tiksliau suvokti, kokia yra šalies rizika ir i ką vyriausybei reikètų sutelkti dèmesị bei pastangas siekiant pagerinti situaciją. Nuosekliai išvystytų ir bendrai priimti finansinio stabilumo rodikliu stebėsena, raidos analizè padeda ịvertinti ilgalaikę šalies rizikos elgseną.

\subsection{Palūkanų normų ir kredito reitingų kaip šalies rizikos matavimo būdų apžvalga}

Finansinės integracijos kliūtys, ekonominès sąlygos ir struktūriniai skirtumai euro zonos narių bankų rinkose sukuria sistemingus tarpvalstybinius bankų paskolų palūkanų normų skirtumus. Atitinkamoje literatūroje plačiai sutariama, kad vienos kainos įstatymas euro zonos bankų rinkose niekada nebuvo igyvendintas, o 2008-2011 m. finansų ir skolų krizè turèjo neigiamos įtakos palūkanų normų konvergencijos procesui euro zonoje ir Europos Sajungoje.

Valstybès obligacijų pajamingumas daro įtaką bankų paskolu palūkanų normoms daugiausia trimis būdais: a) per kainų nustatymo kanalą, nes vyriausybės obligacijų pajamingumas yra palūkanų normos nustatymo bankų sistemoje etalonas; b) per balanso efektą, nes bankų kapitalo prieaugis ar nuostoliai dèl jų obligacijų portfelio sukelia svyravimus kredito pasiūloje, taigi ir palūkanų normoje; c) per likvidumo kanalą, nes praradus obligacijų vertę sumažèja banko galimybė pasisavinti lešas iš pinigų rinkos, panaudojant obligacijas kaip užstatą (Michalopoulos ir Tsermenidis, 2018).

Šalies rizika, apimanti daugybę ịvairių situacijų, užsienio investuotojui taip pat reiškia ir specifinę riziką, kurią ji sukelia, kad ir koks būtų rizikos šaltinis ir pramonès rūšis. Kaip pastebèjo Belke ir Klose (2020), nuo 2008 m., kuomet buvo pastebetos akivaizdžios finansų krizès apraiškos, palūkanų normos buvo gerokai išaugusios. Todèl galima pagrịstai manyti, kad palūkanų mažèjimas ar didejjimas atitinkamai tiesiogiai proporcingas ekonominès bei politinès situacijos gerèjimui ar prastèjimui.

Vertinant šalies rizikingumą finansų rinkose dažnai pasitikima kredito ir rizikos reitingavimo agentūrų pateikiamomis ižzalgomis. Taigi, kredito reitingas - tai rodiklis, atskleidžiantis investuotojams, ar skolininkas yra mokus/igalus gražinti pasiskolintus pinigus t. y. tikslingai vykdyti savo įsipareigojimus. Kredito reitingai turi reikšmingą ịtaką finansinių krizių, recesijų ar tiesiog ekonominio nuosmukio metu. Netikslus ịvertinimas gali sukelti drastiškų padarinių. Tačiau kredito reitingas, t. y, prognozė dẻl potencialaus ar esamo skolininko finansinès būklès, nesuteikia jokių garantijų, kad investuotojai gaus laukiamos naudos, taip pat jis neturi įtakos tokiems svarbiems investavimo aspektams kaip likvidumas ar atitinkamo turto kainų stabilumas (Akins, 2017).

\subsection{CDS sandorių kaip šalies rizikos vertinimo priemonių apžvalga}

Kredito ịsipareigojimų neįvykdymo apsikeitimo sandoris (CDS) yra išvestinè finansinė priemonė arba sutartis, leidžianti investuotojui „apsikeisti“ savo kredito rizika arba ją kompensuoti su kitu investuotoju. Standartinis CDS kainų nustatymo modelis pagristas prielaida, kad nèra kitos sandorio šalies rizikos. Iš tikrujų sandorio šalies rizika tapo viena pavojingiausių CDS rinkos grèsmiụ. Jau kurị laiką yra žinoma, kad, siekiant tinkamai ịvertinti CDS, turi būti atsižvelgiama ị sandorio šalies poveikị (White, 2018). Be to, verta atkreipti dèmesị i faktą, kad dèl tarpusavio ryšio, kai prekiautojai yra tarpusavyje susiję per ne biržos išvestinių finansinių priemonių grandines, padidejja užkrètimo rizika. Dèl savo koncentracijos ir tarpusavio ryšio CDS rinka kelia sisteminę riziką finansų rinkos stabilumui. Kredito įsipareigojimų neįvykdymo apsikeitimo sandoriai (CDS) gali būti taikomi kaip bankų rizikos rodiklis. Taip pat, remiantis užsienio tyrèjų rezultatais, galima pastebėti, kad sisteminė šalies rizika didèja, kai po bendro šoko t. y. iš esmès vienodo CDS maržos padidèjimo, pasiskirsčius tolygiai pagal šaliai sistemiškai svarbius bankus ir jų veiklos rizikingumą (Ballester et al., 2016).

Po praeitame dešimtmetyje vykusios finansų krizès žymiai išaugo CDS sandorių naudojimas. Tarp investuotojų vyrauja ịsitikinimas, kad, jei CDS yra visiškai ịkeistas, nėra jokios kredito rizikos. İkeitimo paskelbimo režimai iš pradžių buvo sukurti ir naudojami dvišaliams rizikos produktams, pvz., palūkanų normos apsikeitimo sandoriui (IRS), taigi:

- CDS sutarčių verte ịprastai staiga kinta dideliais šuoliais, kadangi IRS sutarčių kainų pokyčiai yra daug sklandesni ir mažiau nestabilūs nei CDS kainos.

- CDS pasiskirstymas gali labai greitai plèstis.

- CDS sutartys turi daug daugiau rizikos veiksnių nei IRS sutartys.

Pagal White (2018), jo išnagrinètas modelis atskleidžia, kad visiškai ikkeistas CDS nèra lygiavertis nerizikingam, todèl užtikrinimo priemonès, skirtos sušvelninti sandorio šalies riziką, gerai veikia ir finansines priemones, kurioms taikoma dvišalè kredito rizika, tačiau žlunga tos, kurioms taikoma daugiašalè kredito rizika.

Taigi, CDS yra naudojamas valstybių, vengiant didesnès rizikos ir tam tikrais atvejais gaunant pagalbą, tačiau CDS yra vertinamas nevienareikšmiškai. Visiškas ịkeitimas negali pašalinti kitos CDS sandorio šalies rizikos. 


\section{Tyrimo metodika}

Pirmoje darbo dalyje apžvelgta, kas yra šalies rizika, iš ko ji susideda ir kaip ji yra vertinama, aptareme finansinio patikimumo sampratą, taip pat atlikome palūkanų normų ir kredito reitingų apžvalgą, aptarėme kredito ịsipareigojimų neịvykdymo apsikeitimo sandorị (CDS).

Šioje dalyje aptarsime, kokius metodus taikysime tikslui pasiekti, t. y. sužinosime, kurie metodai padès tiksliausiai nustatyti riziką Baltijos šalyse. Taikysime kiekybinius metodus - Pearsono koreliacinę ir regresinę analizę tarp Baltijos šalių skolos ir Vokietijos infliacijos, siekiant palyginti bei nustatyti rodiklių priklausomumą tarpusavyje. Vokietijos infliaciją fiksuojame kaip atskaitos objektą, nes ji yra aiški euro zonos lyderè, užima reikšmingą vietą pasaulio ir ES ekonomikoje, jos socialinė gerovė yra viena iš aukščiausio lygio Europoje ir pasaulyje, ekonomikos konkurencingumas yra tvarus, o jos ūkio vystymasis - stabilus ir subalansuotas. Tuomet SAW metodu (Simanavičienė, 2013) nustatome rizikingiausią Baltijos šalį, todèl reikšmès skaičiavimuose Lietuva, Latvija ir Estija, o kintamieji, pagal kuriuos nustatysime rizikingumą, yra BVP, biudžetas, infliacija, nedarbo lygis, o metus pasirinksime 2018. Parodysime, kaip keitėsi Baltijos šalių ịsiskolinimo lygis nuo $2000 \mathrm{~m}$, bei palyginsime reitingus. Visi nagrinèjami duomenys bus pateikiami 2000-2018 m. laikotarpio. Visi duomenys kiekybiniams tyrimams atlikti buvo gauti iš antrinių šaltinių (Statistiniai duomenys, 2019).

Taigi pradžiai koreliacinèje regresinėje analizėje pasirinktas reikšmingumo lygmuo $\alpha=0,05$, todèl sprendimo patikimumas yra 95 proc., o galimų klaidų 5 proc. Pearsono koreliacijos koeficiento reikšmè gali būti tarp +1 ir -1 , o jei reikšmé nulinè - ryšio nèra (Lietuvos HSM duomenų archyvas, 2019).

$$
\hat{p}=r=\frac{x^{\prime} y-x^{\prime} \cdot y^{\prime}}{\sqrt{x^{\prime 2}-}} .
$$

Sudarysime regresijos lygtis siekdami statistiškai ịvertinti Baltijos šalių ir Vokietijos rodiklių tarpusavio priklausomumą. Taikant SAW metodą ịvertinama visų rodiklių pasvertų normuotų reikšmių suma $S_{j}$ kiekvienam $j$-tajam objektui taikant šią formulę (V. Podvezko ir A. Podviezko, 2013):

$$
S_{j}=\sum_{i=1}^{m} w_{i} r_{i j}^{\prime}
$$

čia: $w_{i}-i$-tojo kriterijaus svoris; $r_{i j}^{\prime}$ - normuotas $j$-tojo objekto $i$-tojo kriterijaus reikšmes; $i=1, \ldots, m ; j=1, \ldots, n$; $m$ - kriterijų skaičius; $n$ - objektų / alternatyvų skaičius. Sudarius pirminę sprendimo matricą, jos pradinius duomenis normuojame pagal žemiau pateiktas formules :

$$
\begin{gathered}
r_{i j}^{\prime}=\frac{\min _{j} r_{i j}}{r_{i j}} \text {, kai šalių rodikliai sumažinami iki minimumo. } \\
r_{i j}^{\prime}=\frac{r_{i j}}{\max _{j} r_{i j}} \text {, kai šalių rodikliai sumažinami iki maksimumo. }
\end{gathered}
$$

Siekiant nustatyti, kuri Baltijos šalis yra rizikingiausia (max), prieš matricos normavimą ịvertinama, kuri kiekvieno kintamojo reikšmė yra didžiausia, iš kurios taikant (2) formulę, kiekviena atitinkamo kintamojo reikšme padalinama, ir gaunami normuoti sprendimo matricos elementai. Dauginant rodiklių reikšmingumus iš gautos normuotos sprendimų matricos elementų, sudaroma svertinė normuota matrica. Šiuo atveju gautas atitinkamu reikmių svoris buvo 0,25 ( 1 dalintas iš 4 kriterijų). Rangavimas atliekamas susumuojant kiekvieno kriterijaus reikšmes. Kadangi taip pat nustatinėsime nepriklausomus reitingus Lietuvoje nuo 2000 m., tai pateikiama 5 lentelè su kredito reitingų reikšmèmis.

5 lentelè. Kredito reitingų reikšmès (Lietuvos Respublikos finansų ministerija, 2019)

\begin{tabular}{|c|c|c|}
\hline \multicolumn{2}{|c|}{ Ilgalaikio skolinimosi reitingai } & \multicolumn{1}{c|}{ Apibūdinimas } \\
\hline AAA & 10 & Aukščiausias saugumo lygis \\
\hline AA+ & 9 & Aukštas saugumo lygis \\
\hline AA & 8 & Aukštas saugumo lygis \\
\hline AA- & 7 & Aukštas saugumo lygis \\
\hline A+ & 6 & Aukštesnis investicinis reitingas \\
\hline A & 5 & Aukštesnis investicinis reitingas \\
\hline A- & 4 & Aukštesnis investicinis reitingas \\
\hline
\end{tabular}


5 lentelès pabaiga

\begin{tabular}{|c|c|c|}
\hline \multicolumn{2}{|c|}{ Ilgalaikio skolinimosi reitingai } & Apibūdinimas \\
\hline BBB + & 3 & Žemesnis investicinis reitingas \\
\hline BBB & 2 & Žemesnis investicinis reitingas \\
\hline BBB- & 1 & Žemesnis investicinis reitingas \\
\hline
\end{tabular}

\section{Baltijos šalių rizikos vertinimas}

Dèl duomenų neprieinamumo negalime atlikti šalių rizikos vertinimo lyginamosios analizès naudodamos informaciją apie CDS sandorių maržą finansų rinkose.

Atlikus koreliacinę ir regresinę analizę tarp Vokietijos infliacijos (žr. 6 lentelę) ir Baltijos šalių įsiskolinimo lygio nuo $2000 \mathrm{~m}$. iki $2018 \mathrm{~m}$. galima ịvertinti priklausomumą tarp šių dydžių.

6 lentelè. Infliacijos lygis Vokietijoje 2000-2018 m. (ES statistiniai duomenys, 2019)

\begin{tabular}{|c|c|}
\hline Metai & Infliacija, proc. \\
\hline 2000 & $2 \%$ \\
\hline 2001 & $1,61 \%$ \\
\hline 2002 & $1,14 \%$ \\
\hline 2003 & $1,12 \%$ \\
\hline 2004 & $2,22 \%$ \\
\hline 2005 & $1,41 \%$ \\
\hline 2006 & $1,39 \%$ \\
\hline 2007 & $3,17 \%$ \\
\hline 2008 & $1,13 \%$ \\
\hline 2009 & $0,81 \%$ \\
\hline 2010 & $1,31 \%$ \\
\hline 2011 & $1,98 \%$ \\
\hline 2012 & $2,04 \%$ \\
\hline 2013 & $1,43 \%$ \\
\hline 2014 & $0,19 \%$ \\
\hline 2015 & $0,17 \%$ \\
\hline 2016 & $1,50 \%$ \\
\hline 2017 & $1,38 \%$ \\
\hline 2018 & $1,56 \%$ \\
\hline &
\end{tabular}

7 lentelëje pateikti koreliacinès analizès rezultatai, gautos regresijos lygtys, $F$ kritinès, $F$ apskaičiuotosios bei determinacijos koeficientų atitinkamas reikšmès:

7 lentelè. Vokietijos infliacijos ir Baltijos šalių skolos (2000-2018 m.) koreliacijos ir regresijos skaičiavimai (sudaryta autorių)

\begin{tabular}{|l|c|c|c|}
\hline & Lietuvos skola, proc. & Latvijos skola, proc. & Estijos skola, proc. \\
\hline $\begin{array}{l}\text { Vokietijos (ataskaitos taškas) } \\
\text { infliacija (koreliacija) }\end{array}$ & $-0,36178$ & $-0,34023$ & $-0,46411$ \\
\hline $\begin{array}{l}\text { Vokietijos infliacija (regresijos } \\
\text { lygtis) }\end{array}$ & $y=36,66175-5,33648 x$ & $y=37,40411-7,12547 x$ & $y=9,293028-1,60622 x$ \\
\hline Vokietijos infliacija (F kritinė) & 4,4513 & 4,4513 & 4,4513 \\
\hline $\begin{array}{l}\text { Vokietijos infliacija } \\
(F \text { apskaičiuotoji) }\end{array}$ & 17 & 17 & 17 \\
\hline $\begin{array}{l}\text { Vokietijos infliacija } \\
\text { (determinacijos koeficientas) }\end{array}$ & 0,1309 & 0,1158 & 0,215395 \\
\hline
\end{tabular}

Koreliaciją tarp Vokietijos infliacijos ir Baltijos šalių ịsiskolinimo lygio koreliacija gavosi neigiama, kintanti intervale $[-0,5 ;-0,4]$. Taigi, priklausomybė tarp Vokietijos infliacijos ir Baltijos šalių ịsiskolinimo lygio yra vidutinio intensyvumo, tačiau daro tam tikrą poveikị ịsiskolinimo lygio raidai. Ištyrus Baltijos šalių ịsiskolinimo lygio priklausomybę nuo Vokietijoje fiksuotos infliacijos, gauta regresijos lygtis tarp Lietuvos įsiskolinimo lygio ir Vokietijos infliacijos:

$$
y=36,66175-5,33648 x \text {. }
$$


Remiantis (4) regresijos lygtini, galima teigti, kad jei Vokietijos infliacija padidètų vienu procentu, Lietuvos įsiskolinimo lygis sumažètų 5,34 proc. punkto Rezultatai adekvatūs realiai situacijai esant $95 \%$ tikimybei, kadangi apskaičiuotoji Fisherio skirstinio $F$ reikšmė (17) yra didesnè už $F$ kritinę $(4,4513)$. Determinacijos koeficientas $R^{2}=$ 0.1309 rodo, kad $13 \%$ Lietuvos įsiskolinimo lygio kaitos lemia infliacijos pokytis Vokietijoje. Kitus $87 \%$ lemia kiti ì regresijos lygti neįtraukti veiksniai. Kita regresijos lygtis aprašo atitinkamą Latvijos ịsiskolinimo lygio priklausomybę nuo Vokietijos infliacijos

$$
y=37,40411-7,12547 x .
$$

Šiuo atveju determinacijos koeficientas $R^{2}=0.1158$ rodo, kad $12 \%$ Latvijos ịsiskolinimo lygio kaitos lemia infliacijos pokytis Vokietijoje. Kitus $88 \%$ lemia kiti ị regresijos lygti neịtraukti veiksniai. Dar viena regresijos lygtis apibūdina Estijos įsiskolinimo lygio priklausomybę nuo Vokietijos infliacijos:

$$
y=9,293028-1,60622 x \text {. }
$$

Determinacijos koeficientas $R^{2}=0.215395$ rodo, kad $22 \%$ Estijos įsiskolinimo lygio kaitos lemia infliacijos pokytis Vokietijoje. Kitus $78 \%$ lemia kiti ị regresijos lygtị neịtraukti veiksniai.

Remiantis gautais rezultatais galima daryti išvadas, kad Vokietijos infliacija daro gana silpną ịtaką Baltijos šalių ịsiskolinimo lygio, taip pat ir rizikos raidai. Panašu, kad kiti ekonominiai ir neekonominiai veiksniai šiam dydžiui daro didesnę įtaką.

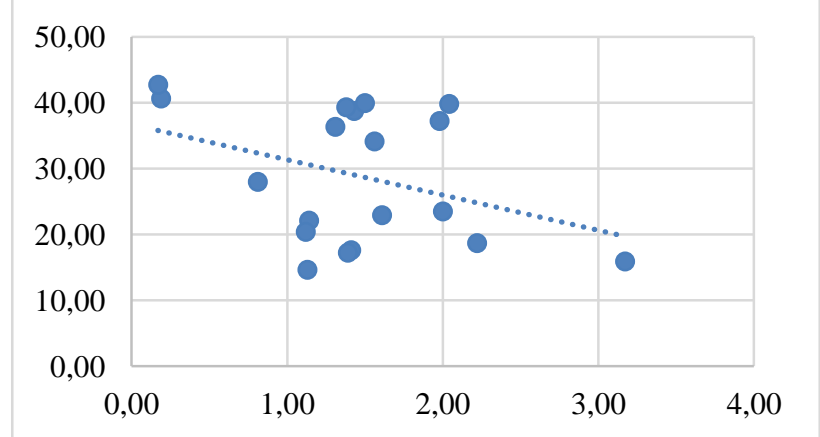

1 paveikslas. Regresijos lygtis ir sklaida Lietuvos atveju (sudaryta autorių)

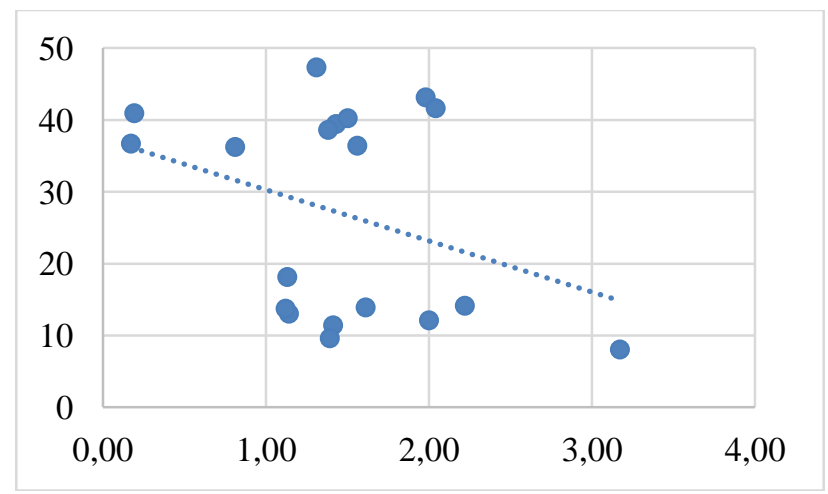

2 paveikslas. Regresijos lygtis ir sklaida Latvijos atveju (sudaryta autorių)

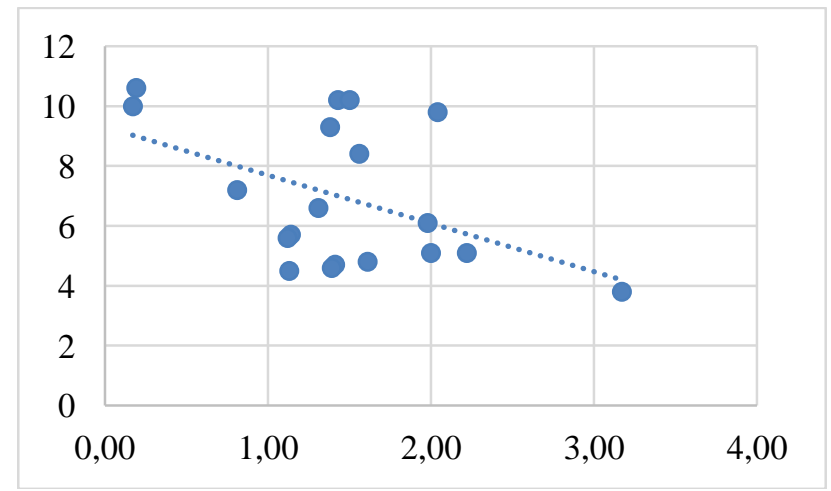

3 paveikslas. Regresijos lygtis ir sklaida Estijos atveju (sudaryta autorių) 
Atlikus regresinę analizę, galima pastebėti, kad analizuojamų dydžių reikšmių sklaida apie regresijos tiesę yra gana didelè, tai galime matyti visose trijose regresijose pateiktose aukščiau (1 paveikslas, 2 paveikslas, 3 paveikslas). Galime daryti išvadą, kad Vokietijoje fiksuota atitinkamo laikotarpio infliacija dare gana silpną poveikį Baltijos šalių ịsiskolinimo raidai.

Siekiant išsamesnių reitingavimo rezultatų, taikytas SAW (angl. Simple Additive Weighting) metodas (Ibrahim ir Surya, 2019). Atliekant reitingavimą taikant SAW metodą naudotasi 4 veiksniais: BVP, infliacija, nedarbo lygis ir valstybès biudžetas (žr. 8 lentelę).

8 lentelè. SAW rezultatai (sudaryta autorių)

\begin{tabular}{|l|c|c|c|}
\hline & Lietuva & Latvija & Estija \\
\hline$S j$ & 0,8698 & 0,7304 & 0,8480 \\
\hline Rangas & 1 & 3 & 2 \\
\hline
\end{tabular}

Pritaikius šị metodą gauti rezultatai liudija, kad rizikingiausia šalis yra Lietuva $(0,9)$, tuomet Estija $(0,8)$, o mažiausia riziką iš Baltijos šalių turi Latvija - 0,7.

4 paveiksle galima pastebèti, jog Estijos įsiskolinimas buvo mažiausias tarp Baltijos šalių.

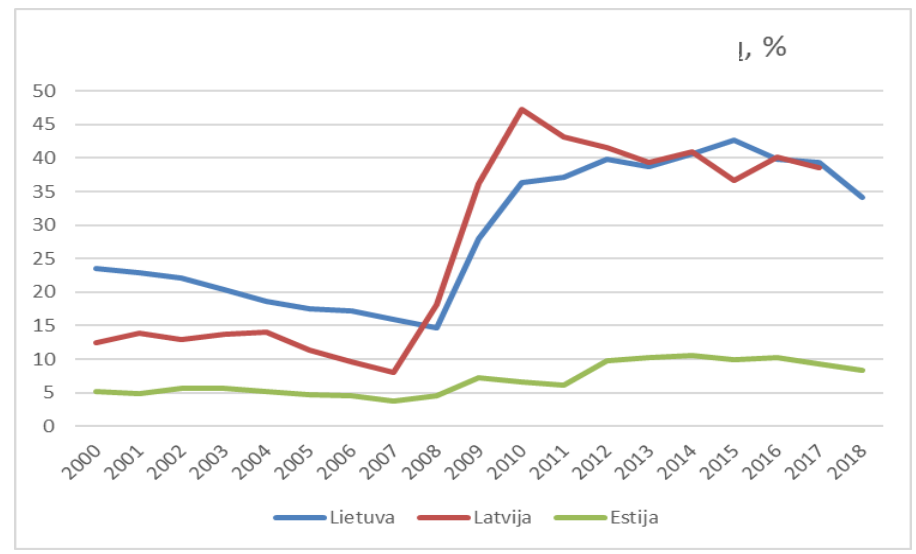

4 paveikslas. Baltijos šalių ịsiskolinimo lygio raida nuo 2000 m., \% (sudaryta remiantis ES statistiniais duomenimis)

Galima pastebėti, kad krizès laikotarpiu, t. y. 2008-2011 m. šalių skolos ir šalies įsiskolinimo lygis išaugo, ypač Lietuvoje (nuo 14,6 proc. iki 37,2 proc. BVP) ir Latvijoje (18,1 proc. iki 43,1 proc. BVP). Estijoje šalies skola išaugo mažiausiai (nuo 4,5 proc. iki 6,1 proc. BVP). Po krizès laikotarpio Baltijos šalių skolos pradejo santykinai mažèti tik nuo maždaug 2017 m. Latvijoje ir Lietuvoje issiskolinimo lygis buvo panašios apimties, tačiau Latvijoje skolos sparčiai pradejo augti būtent nuo 2008 m., o Lietuvoje - nuo 2009 m. Vertinant Baltijos šalis pagal ịsiskolinimo lygi, galima konstatuoti, kad santykinai mažiausiai įsiskolinusi buvo Estija, o Latvijos ir Lietuvos ìsiskolinimas analizuojamu laikotarpiu išliko panašus.

9 lentelëje pateikti Baltijos šalių nepriklausomi kredito reitingai, kurie buvo nurodyti Standard \& Poor's agentūros. Šioje lentelèje yra nurodyti tik ilgalaikių paskolų, išduotų nuo 2000 m. iki 2018 m., reitingai. Galima pastebèti, kad nuo 2008 m. ir iki pat 2013 m. Lietuvos reitingai buvo suprastèję nuo A iki BBB, tačiau nuo 2014 m. reitingai tapo A- (aukštesnis investicinis reitingas), o $2018 \mathrm{~m}$., kadangi bendra ekonominè padètis gerèjo, reitingas jau igijo A reikšmę. Latvijoje krizès laikotarpiu reitingai išsilaikè panašiame lygyje (BBB; žemesnis investicinis reitingas), o Estijos reitingai buvo išsilaikę aukštame ir aukštesniame saugumo lygyje.

9 lentelè. Nepriklausomi reitingai Baltijos šalyse nuo $2000 \mathrm{~m}$. (sudaryta autorių, remiantis Standard \& Poor's nepriklausomais reitingais)

\begin{tabular}{|c|c|c|c|}
\hline \multirow{2}{*}{ Metai } & \multicolumn{3}{|c|}{ Ilgalaikès paskolos } \\
\cline { 2 - 4 } & Lietuva & Latvija & Estija \\
\hline 2000 & BBB- & BBB & BBB+ \\
\hline 2001 & BBB- & BBB & A- \\
\hline 2002 & BBB & BBB+ & A- \\
\hline 2003 & BBB+ & BBB+ & A- \\
\hline 2004 & A- & A- & A \\
\hline 2005 & A & A- & A \\
\hline
\end{tabular}


9 lentelès pabaiga

\begin{tabular}{|c|c|c|c|}
\hline \multirow{2}{*}{ Metai } & \multicolumn{3}{|c|}{ Ilgalaikès paskolos } \\
\cline { 2 - 4 } & Lietuva & Latvija & Estija \\
\hline 2006 & A & A & A \\
\hline 2007 & A & BBB+ & A \\
\hline 2008 & BBB+ & BBB & A- \\
\hline 2009 & BBB & BBB+ & A- \\
\hline 2010 & BBB & BBB+ & A \\
\hline 2011 & BBB & BBB- & AA- \\
\hline 2012 & BBB & BBB & AA- \\
\hline 2013 & BBB & BBB+ & AA- \\
\hline 2014 & A- & A- & AA- \\
\hline 2015 & A- & A & AA- \\
\hline 2016 & A- & A- & AA- \\
\hline 2017 & A- & A & AA- \\
\hline 2018 & A & A & AA- \\
\hline
\end{tabular}

Pagal 9 lentelę galime pastebèti, kad aukščiausius kredito reitingus iš Baltijos šalių turinčios Estijos kredito reitingai nuo 2000 m. iki 2018 m. pagerèjo, o nuo 2011 m. išliko tame pačiame lygyje. Lietuvai ir Latvijai priskirti kredito reitingai visą šį laikotarpi šiek tiek keitèsi, tačiau niekada nepasiekė Estijai suteikto reitingo lygio. Iš esmės tai atitinka skirtingą ilgalaikị šių šalių vyriausybių požiūrị ị fiskalinę drausmę, o labiausiai - valstybès biudžeto deficito valdyseną, ị kurią dèmesị taip pat kreipia ir investuotojai. 2011-2013 m. Baltijos šalims priskirtos kredito reitingų reikšmės, atitikdamos dèl ịvykdytų reformų, gerejjančią ekonominę situaciją, gana griežtos fískalinės drausmès politiką ir efektyvų valstybès skolos valdymą, pradèjo gerèti, ir tai atitinka tendencingą makroekonominès aplinkos verslui steigti ir plètoti gerejjimą.

\section{Išvados}

Investuotojai, siekdami suprasti, ar gali saugiai investuoti tam tikrame regione ar konkrečioje šalyje, taiko ne vieną metodą, siekdami nustatyti, ar šalis yra tinkama investavimui.

Apskaičiavus koreliaciją tarp atitinkamo laikotarpio Vokietijos infliacijos ir Baltijos šalių įsiskolinimo lygio galima konstatuoti, kad priklausomybė tarp šių dydžių yra gana nereikšminga. Atlikus skaičiavimus regresijai gauti, matome, kad rodiklių sklaida apie regresijos tiesę yra didelè, tai galime matyti visose trijose regresijose. Galime daryti išvadą, kad Vokietijoje stebima infliacija nepakankamai paaiškina Baltijos šalių ịsiskolinimo raidai ir jau turi gana silpną poveikị.

Pritaikius SAW metodą, nustatyta, kad iš Baltijos šalių rizikingiausia šalis yra Lietuva $(0,9)$, tuomet Estija $(0,8)$, o mažiausia riziką iš Baltijos šalių turi Latvija $(0,7)$.

Apibendrinus visus rezultatus galima teigti, kad Lietuva turi didžiausią riziką tarp Baltijos šalių ir kad Baltijos šalims daro nedidelę itaką, kuomet kinta bendras infliacijos lygis, kaip pvz., Vokietijoje.

Taip pat išanalizavusios, kaip keitèsi Baltijos šalių ịsiskolinimo lygis nuo $2000 \mathrm{~m}$. iki $2018 \mathrm{~m}$. ir praejjus giliausiam finansų krizès laikotarpiui, Baltijos šalių kredito reitingai kaip šalies rizikos matai išlieka arba gerèjantys, arba stabilūs, ir tai atitinka šalių ịsiskolinimo lygio raidą. Atsižvelgiant ị platesnị euro zonos skolų krizès kontekstą galima daryti išvadą, kad Baltijos šalys, nors ir išgyvenusios smarkų ekonomikos smukimą 2008$2011 \mathrm{~m}$. dèl igyvendinamos gana griežtos fiskalinès politikos investuotojų laikomos patikimomis. Tačiau pagrindinę investicijoms šiame regione riziką kelia ne makroekonominė aplinka, o geopolitiniai procesai, palyginti mažai priklausantys nuo pačių šalių vyriausybių pastangų.

\section{Literatūra}

Akins, B. (2017). Financial reporting quality and uncertainty about credit risk among ratings agencies. The Accounting Review, 93(4), 1-22. https://doi.org/10.2308/accr-51944

Ballester, L., Casu, B., \& González-Urteaga, A. (2016). Bank fragility and contagion: Evidence from the CDS market. Journal of Empirical Finance, 38(A), 394-416. https://doi.org/10.1016/j.jempfin.2016.01.011

Belke, A., \& Klose, J. (2020). Equilibrium real interest rates and the financial cycle: Empirical evidence for Euro area member countries. Economic Modelling, 84, 357-366. https://doi.org/10.1016/j.econmod.2019.04.025

Damodaran, A. (2018). Country risk: determinants, measures and implications - the 2018 edition. https://doi.org/10.2139/ssrn.3217944

Dumalakas, J. (2018). Makroprudencines politikos prigimtis ir legitimumas (Doctoral dissertation, Vilnius University). http://epublications.vu.lt/object/elaba:35370517/ 
ES statistiniai duomenys. (2019). https://ec.europa.eu/eurostat/statisticsexplained/index.php?title=Structure_of_government_debt

Freitakas, E. ir Mendelsonas, T. (2016). Šalies finansinio stabilumo matavimo metodai. Tiltai, 75(3), 61-76. https://doi.org/10.15181/tbb.v75i3.1424

Haldane, A. G., Hoggarth, G., Saporta, V., \& Sinclair, P. (2004, September 30). Financial stability and bank solvency. Paper presented at the Federal Reserve Bank of Chicago International Conference, Chicago, Illinois. https://doi.org/10.1142/9789812569479_0007

Husted, B. W., \& de Sousa-Filho, J. M. (2017). The impact of sustainability governance, country stakeholder orientation, and country risk on environmental, social, and governance performance. Journal of Cleaner Production, 155, 93-102. https://doi.org/10.1016/j.jclepro.2016.10.025

Ibrahim, A., \& Surya, R. A. (2019). The implementation of Simple Additive Weighting (SAW) method in decision support system for the best school selection in Jambi. Journal of Physics: Conference Series, 1-7. https://doi.org/10.1088/1742-6596/1338/1/012054

Karazijienè, Ž. ir Sabonienè, A. (2009). Valstybès skolos struktūra ir valstybès skolinimosi ịtaka Lietuvos ekonomikai. Ekonomika ir vadyba, (14), 271-279. https://etalpykla.lituanistikadb.lt/object/LT-LDB-0001:J.04 2009 1367168447290/

Lietuvos HSM duomenų archyvas. (2019). Statistinè kiekybiniu duomenu analizè su SPSS ir STATA. https://www.lidata.eu/index.php?file=files/mokymai/stat/stat.html\&course_file=stat_III_4_1.html

Lietuvos Respublikos finansų ministerija. (2019). Kredito reitingu apžvalga. https://finmin.lrv.lt/lt/veiklos-sritys/valstybesskolos-valdymas/kredito-reitingai/kredito-reitingu-reiksmes

Liu, C., Sun, X., Chen, J., \& Li, J. (2016). Statistical properties of country risk ratings under oil price volatility: Evidence from selected oil-exporting countries. Energy Policy, 92, 234-245. https://doi.org/10.1016/j.enpol.2016.02.007

Liu, J., Wei, W., Shi, Y. B., \& Chang, C. P. (2020). The nexus between country risk and exchange rate regimes: A global investigation. The North American Journal of Economics and Finance, 51, 100842. https://doi.org/10.1016/j.najef.2018.08.025

Michalopoulos, G., \& Tsermenidis, K. (2018). Country risk on the bank borrowing cost dispersion within the euro area during the financial and debt crises. International Journal of Economics \& Business Administration (IJEBA), 6(4), 7692. https://doi.org/10.35808/ijeba/176

Pati, A. P. (2017). Credit risk stress testing practices in BRICS: Post-global financial crisis scenario. Global Business Review, 18(4), 936-954. https://doi.org/10.1177/0972150917692269

Podvezko, V. ir Podviezko, A. (2013). Naujos absoliutaus daugiakriterio vertinimo galimybès. Lietuvos matematikos rinkinys, 54, 54-59. https://scholar.google.lt/scholar?cluster $=8503373340954662786 \& h l=l t \& a s \_s d t=0,5$

Schinasi, G. J. (2004). Defining financial stability (International Monetary Fund Working paper, No. WP/04/187, pp. 1-17). https://doi.org/10.5089/9781451859546.001

Simanavičienè, R. (2013). Statistinių metodų taikymas daugiatikslių sprendimų patikimumui ịvertinti. Informacijos mokslai, 65, 120-126. https://doi.org/10.15388/Im.2013.0.2048

Standard \& Poor's credit ratings. (2019). https://www.standardandpoors.com/en_US/web/guest/home

White, A. (2018). Pricing credit default swap subject to counterparty risk and collateralization. SSRN Electronic Journal. https://doi.org/10.2139/ssrn.3144553

\title{
FINANCIAL STABILITY AND RISK EVALUATION OF THE BALTIC STATES
}

\author{
Veronika DZALBO, Laura GUDELYTE்
}

\begin{abstract}
Targeted country risk assessment is important and is a growing topic with each passing year. Investors use a number of approaches to determine whether a country is suitable for investment to understand if they can safely invest. This article aims to assess the risk in the Baltic States and identify the riskiest country. So, at the beginning, we describe the country risk assessment methods, explain what financial soundness is, review credit ratings, interest rates, CDSs across borders. Then, using correlation, regression, SAW methods and comparative analysis, we will identify the riskiest country in the Baltics.
\end{abstract}

Keywords: economic risk, financial stability, ratings, stability indices, country risk, country risk assessment methods. 